\title{
Value-Based CRM
}

\section{The Interaction of the Triad of Marketing, Financial Management, and IT}

\section{Customer relationships represent a firm's most valuable assets. Within value-based} management it is therefore crucial that customer relationships should be treated as assets or investments that need to be actively managed to maximize corporate value. However, (mono-)disciplinary approaches often do not explore the true economic potential of CRM. Therefore, this paper first presents the state of the art of CRM in academia and practice in general. Furthermore, specific challenges of a value-based CRM for the interaction between marketing, financial management, and IT are analyzed in detail. In addition to a mutual alignment of marketing and IT, the development of financial performance measures is crucial. Based on these measures and on an adequate IT support, the contribution of CRM to the corporate value can be measured and controlled.

DOI 10.1007/s12599-010-0095-7

\section{The Author}

Dr. Martin S. Gneiser ( $\varangle)$

University of Augsburg

FIM Research Center Finance \&

Information Management,

Department of Information Systems

Engineering \& Financial

Management

Universitätsstraße 12

86159 Augsburg

Germany

martin.gneiser@wiwi.uni-augsburg.de

url: http://www.fim-online.eu

Received: 2009-03-31

Accepted: 2009-08-17

Accepted after one revision by

Prof. Dr. Buxmann.

Published online: 2010-03-03
This article is also available in German in print and via http://www. wirtschaftsinformatik.de: Gneiser MS (2010) Wertorientiertes CRM. Das Zusammenspiel der Triade aus Marketing, Finanzmanagement und IT. WIRTSCHAFTSINFORMATIK. doi: 10. 1007/s11576-010-0214-6.

(C) Gabler Verlag 2010

\section{Introduction}

Today, many companies operate in stagnant markets with a high degree of competition, increasing customer demands, and easily substitutable products and services. Moreover, and due to the evolution of marketing from a product- and transaction-oriented to a customer- and relationship-oriented perspective, there has been an increasing focus on customer relationships both in research and practice in the past two decades (Elmuti et al. 2009, p. 75; Reinartz et al. 2004, p. 293). Therefore, many companies consider customer relationships as key assets
(Kumar et al. 2004, p. 61). Especially in crisis situations such as the current financial and economic crisis, the importance of solid customer relationships and a balanced customer portfolio for the company's survival becomes apparent. In the light of a value-based management it is therefore not surprising that interests and corporate decision making are increasingly focused on the relationship to the customer.

Customer relationship management (CRM) has emerged as an important research field especially within marketing $^{1}$ and business and information systems engineering (BISE) (Hippner 2005, p. 131; Riemer et al. 2002, p. 600). Developments in information technology ${ }^{2}$ not only allow for the collection and distribution of customer information within the company (Goldsmith 2004, p. 11), but also make it possible "[to] attain customization, the essence of the customercentric orientation, through the deployment of sophisticated customer relationship management (CRM) systems" (Stefanou et al. 2003, p. 617). This is linked to the many implementations of CRM systems ${ }^{3}$ that can be observed in practice,

\footnotetext{
${ }^{1}$ In this article, the term marketing is understood in a broader sense and - following Ambler (2008, p. 414) - includes all activities of a company aligned to the satisfaction of the customer (i.e. in particular the core areas of CRM: marketing, sales, and service).

${ }^{2}$ In this article IT is understood as the application system and infrastructure layer of business information and communication systems (ICS) (cf. Krcmar 2005, p. 25 ff and vom Brocke et al. 2009, p. 262).

${ }^{3}$ We consider a CRM-system (based on Stahlknecht and Hasenkamp 2005, p. 326) to be the whole of the IT infrastructure (consisting of hardware, software, data, storage technology, communication, and network) which is used to support a company's CRM.
} 
in order to ensure synchronization and operational support for customer-related processes within the "classical" core areas of CRM (marketing, sales, and service). According to a comprehensive study by Sackmann et al. (2008, p. 23), nearly $85 \%$ of the companies surveyed have implemented CRM systems. Apart from a growth forecast of Germany-wide IT investments in CRM to more than 2 billion Euros by the end of 2010 (Seidel 2008) an increase of global revenues from license sales of CRM software from nearly 3.6 billion U.S. dollars in 2007 to up to 6.6 billion U.S. dollars in 2012 is estimated (Marketingcharts 2008).

However, despite huge investments numerous studies in business practice illustrate that many CRM projects fail to achieve their objectives (Becker et al. 2009; Elmuti et al. 2009, p. 76). In particular, CRM projects have mainly focused on a system implementation without considering that this is only one component of a successful CRM strategy (Reinartz et al. 2004, p. 302; Richard et al. 2007, p. 423 f). Thus, not only a customer-centric design of the business model as well as the adjustment and alignment of processes, of application systems and of the infrastructure of the company have to be ensured. Rather, within a value-based management all CRM activities and decisions have to be consistently linked to the business goal of an enterprise, i.e. maximizing the long term shareholder value (Bauer et al. 2006, p. 17; Rao and Bharadwaj 2008, p. 16).

What is more, value orientation as a concretization and advancement of the shareholder value approach (SHV) should not only be - as some proponents of SHV-theory claim (Brealey et al. 2007; Keown et al. Equate 2008) - a maximization of the stock price and thus the market capitalization. In this article and according to Rappaport (1986) and Copeland et al. (1993), value orientation is rather understood as a concretization of the SHV with the long-term objective to maximize the net present value of all future cash flows. This long-term orientation, as Danielson et al. (2008) and Albach (2001) show, also leads to compatibility between the SHV and the stakeholder value approach. Moreover, a key performance measure based on the discounted cash flow (DCF) approach ${ }^{4}$ allows for the indirect consideration of nonfinancial measures, which precede the financial dimension as "early indicators" and which finally affect the future cash flows with some delay $(\mathrm{Gu} 2005$; Ittner and Larcker 1998).

Therefore, an integrated, companywide, and value-based CRM requires not only an extension of the considered interface between marketing and IT to the perspective of financial management, but also a cross-functional integration and selectively adjusted collaboration of this resulting triad. A (mono-) disciplinary approach - as it can be found in the majority of marketing management research literature - only insufficiently specifies a CRM concept with regard to a valuebased management (Meyer and Kolbe 2005, p. 176; Zablah et al. 2004, p. 476).

The article addresses this research gap by analyzing the central aspects of a selectively adjusted collaboration of marketing, financial management, and IT in terms of a value-based CRM.

The article is structured as follows: First, we review the research literature regarding CRM and provide a brief overview of the theoretical concept and framework in Sect. 2. In addition to a brief description of the historical development, we identify different perspectives of CRM. A categorization of the functions of CRM systems in Sect. 3 completes the theoretical background for our analysis. In Sect. 4 we then expand the interdisciplinary view of marketing and IT by adding the perspective of financial management which is necessary for a value-based orientation and management of the CRM, and we analyze the interaction of these three fields in detail. The last Sect. summarizes the results and points out areas for further research.

\section{CRM - A Conceptual Overview}

The idea of CRM can be traced back to the field of relationship marketing (RM), which has been introduced by scientific works of Berry (1983), the IMP Group (e.g. Ford 1990), and Christopher et al. (1991). According to Berry
(1983, p. 25), RM is defined as "attracting, maintaining and - in multi-service organizations - enhancing customer relationships". Thereby, RM shifts the focus of transaction marketing, the marketing paradigm dominant up until then, from a general concentration on customer acquisitions and single transactions to long-term customer relationships and individualized products and services. The increasing importance of RM has led to numerous research activities and articles, special issues of academic journals and books. ${ }^{5}$ With the development of IT and the focus on the customer - in the original sense RM deals with all stakeholders and not only with the customer himself (Payne and Frow 2006, p. 137) - CRM emerged from a synthesis of RM and different research streams within marketing and BISE. In a detailed analysis, Hippner (2005, p. $118 \mathrm{f}$ ) distinguishes these into research streams that tend to have a more conceptual marketing background (including database marketing, one-to-one marketing, direct marketing, mass customization) and research streams which tend to have a more technical BISE background (including business process management - e.g. total quality management, business process reengineering - IT integration, information and knowledge management). By means of a consistent alignment of the company and the company's business processes to customers - especially within marketing, sales, and service - CRM focuses on establishing, maintaining, and enhancing long-term relationships with customers (Jayachandran et al. 2005, p. 177).

Although a large number of research articles in the CRM context have been published in the past two decades, there is still no universally accepted definition of CRM (Payne and Frow 2006, p. 138; Ngai 2005, p. 583). Reasons for this can be found in the various disciplinary and interdisciplinary research streams and perspectives on CRM.

Therefore, various attempts have been made in recent years to develop appropriate taxonomies for the CRM concept (see e.g. Buttle 2004; Payne and Frow 2005; Zablah et al. 2004). Due to the complexity of perspectives, this article resorts to the frequently used classification of Zablah et al. (2004) who distinguish five

\footnotetext{
${ }^{4}$ According to Copeland et al. (1993), the DCF approach measures the value of a company by estimating the expected future cash flows, and then discounting those future cash flows with a risk adjusted interest rate.

${ }^{5}$ For an overview cf. e.g. Bush et al. (2006) or Harker and Egan (2006).
} 
Table 1 Dominant perspectives on CRM (according to Zablah et al. (2004))

\begin{tabular}{|c|c|}
\hline Perspective & Exemplary definition \\
\hline Process & $\begin{array}{l}\text { CRM as "... the overall process of building and maintaining profitable customer relationships by delivering superior } \\
\text { customer value and satisfaction" (Kotler and Armstrong 2004, p. 16) }\end{array}$ \\
\hline Strategy & $\begin{array}{l}\text { CRM as "... a business strategy evolved to manage the development of a company, the acquisition and retention of its } \\
\text { customers and to create long-term value between them" (Jackson 2005, p. } 76 \text { ) }\end{array}$ \\
\hline Philosophy & $\begin{array}{l}\text { "CRM is not a discrete project - it is a business philosophy aimed at achieving customer centricity for the company" (Hasan } \\
\text { 2003, p. 16) }\end{array}$ \\
\hline Capability & $\begin{array}{l}\text { CRM “... means being willing and able to change your behavior towards an individual customer based on what the customer } \\
\text { tells you and what else you know about that customer" (Peppers et al. 1999, p. 151) }\end{array}$ \\
\hline Technology & $\begin{array}{l}\text { CRM as "... a technology-enabled business management tool for developing and leveraging customer knowledge to nurture, } \\
\text { maintain, and strengthen profitable relationships" (Raman et al. 2006, p. 40) }\end{array}$ \\
\hline
\end{tabular}

main perspectives (process, strategy, philosophy, capability, and technology). The subject of the analysis of Zablah et al. (2004) was an extensive review of major definitions on CRM in published and working academic papers, CRM web portals as well as definitions offered by the top CRM software manufacturers and providers. Table 1 provides representative conceptualizations of each of the five perspectives on CRM.

At the same time, the prevalence of the technological perspective in business practice is especially caused by the fact that for most companies CRM comes along with implementing a CRM system (Doherty and Lockett 2007, p. II). Therefore, it is not surprising that in business practice CRM is often considered as a synonym for CRM systems (Reinartz et al. 2004, p. 293). Even though studies emphasize that IT plays a substantial role in CRM efforts (Jayachandran et al. 2005), they also reveal that the failure of numerous CRM initiatives can be attributed to the fact that CRM projects are considered as pure IT projects (Da Silva and Rahimi 2007, p. 4). In contrast, for a holistic customer orientation the company's strategic goals and the necessary customer-oriented business processes have to be clearly defined in advance of the implementation.

\section{Classification of the Functionality of CRM Systems}

Modern IT offers many possibilities for supporting CRM. The enhancement of IT and new findings from research and practice lead to the fact that CRM systems are subject to constant change and that their scope and ability is modified by new functions and features. According to Hippner et al. (2007, p. 48) the central task of CRM systems consists in (1) the systematic consolidation and analysis of customer information, (2) the synchronization and support of the central operational CRM processes in marketing, sales, and service, and (3) the integration and management of all communication channels between customers and company. In studies by researchers and CRM software providers on the implementation of CRM systems - for an overview see e.g. Meyer and Kolbe (2005) - the numerous functions are distinguished with regard to three main areas: operational CRM, analytical CRM, and communicative (or collaborative) CRM (Teo et al. 2006, p. 1619). Besides these "classical" application areas and concerning the use of the Internet and mobile communication within CRM and the implementation of CRM in e-commerce and $\mathrm{m}$ commerce, some authors recently proposed an additional classification - which is the electronic CRM ( $\mathrm{eCRM}^{6}$ ) (Xu and Walton 2005, p. 960 f). Due to the lack of a consistent view on or understanding of eCRM in current literature, an explicit classification of eCRM systems is not provided in this article. Fig. 1 illustrates an example of a CRM system architecture and the classification of the functionalities.

Operational CRM includes instruments and applications that support all business areas and their business processes which are in direct contact with customers (front office). The components contribute to IT support and to a large extent to the automation of customer-centric business processes and activities as well as to the integration of customer-oriented applications between front and back office (e.g. ERP or SCM systems), especially in the business areas marketing, sales, and customer service (Iriana and Buttle 2006, p. 23). Typical features of the operational CRM are the campaign, event, and complaint management as well as the sales force support.

Analytical CRM systems are focused on the systematic collection, evaluation, and analysis of all customer contacts and customer reactions including resulting customer-related information (Hippner et al. 2007, p. 49; Iriana and Buttle 2006, p. 28). Information about customers, products, and services are stored, for example, in a customer data warehouse to evaluate, forecast, and optimize customer relationships using analysis tools and techniques (e.g. OLAP and Data Mining). In the process of building a learning system (closed loop architecture) customer actions and reactions can be systematically evaluated. Thus, the customer-oriented business processes and the individual adjustment of the communication and service to the customers' needs can be continually improved (Hippner et al. 2007, p. 49). Via building customer profiles and externalizing behavioral patterns the analytical CRM ensures the support of the strategic and tactical decision-making process (Buttle 2004, p. 10).

Communicative (or collaborative) CRM systems ensure the communication, the synchronization, and the management of individual communication and distribution channels (e.g. branch, Internet) between the company and the customer (Xu and Walton 2005, p. 961). Thus, the implementation of a multi-channel management by providing uniform and consistent information across all channels

${ }^{6}$ According to Schierholz et al. (2006, p. 1) mobile CRM (mCRM) is a subset of eCRM. 


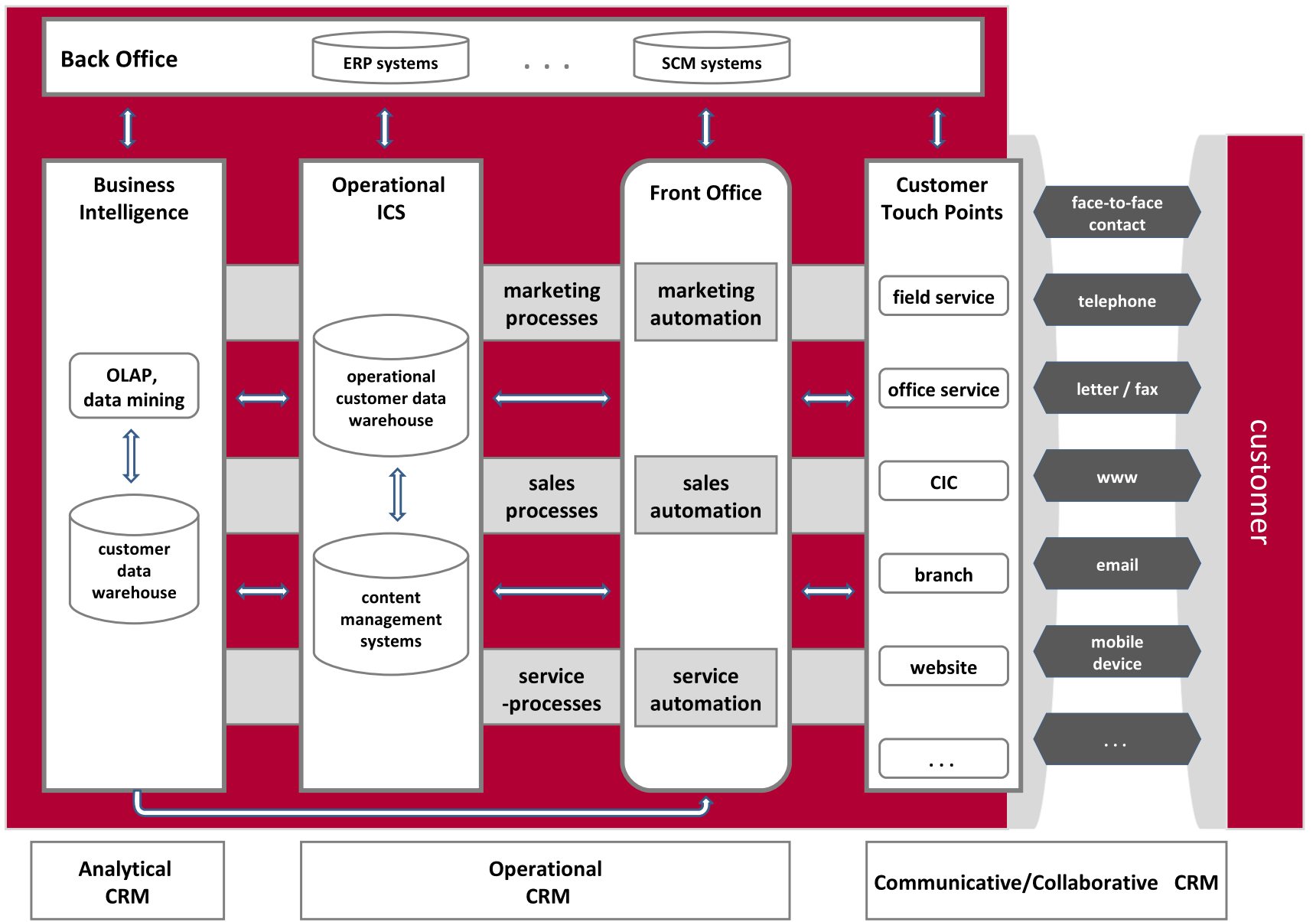

Fig. 1 CRM system architecture (based on Hippner et al. 2007, p. 48)

can be ensured. The Customer Interaction Center (CIC) increasingly takes a central role as a multimedia communication interface. Furthermore, collaborative CRM systems ensure a companywide and cross-company consistent CRM concept by the optimization across the entire value chain (Birker 2008, p. 193).

The coordination of the different types of functionality is crucial for the successful implementation of CRM systems. Thus, the communicative (or collaborative) CRM system is e.g. responsible for providing the results of the analysis and evaluations of the analytical CRM at the right time to the operational CRM via the appropriate channel of interaction. Apart from the alignment of the CRM systems with each other also the integration into the enterprise-wide ICS architecture is necessary to ensure a consistent and holistic view of the customer relationships and to establish a so-called "learning relationship" between the customer and the company (Peppers and Rogers 2001, p. 151).

\section{The Interaction of the Triad of Marketing, Financial Management, and IT}

Due to the increasing importance of CRM and the use of appropriate CRM systems, the establishment and maintenance of long-term customer relationships is central to many corporate activities (Richards and Jones 2008, p. 123). As the successful implementation of CRM requires marketing and IT to work closely together, CRM has developed into an important research field in the interface between marketing and BISE (Richard et al. 2007, p. 422; Wehmeyer 2005, p. 243). Meanwhile, however, not only issues regarding the integration of CRM systems into the existing ICS architecture are in the focus of interest. Furthermore, valuebased management requires the development and enhancement of the ability to account for marketing's contribution to firm performance, i.e. all activities and decision making within marketing have to be based on financial measures to understand the influence on shareholder value (Bauer et al. 2006, p. 17; Rao and Bharadwaj 2008, p. 16). This relevance is also illustrated by the fact that over the past years the internationally renowned Marketing Science Institute (MSI) has included the issue of "marketing productivity" and "marketing metrics" in the list of topics with the highest relevance (Marketing Science Institute 2006). However, only the advanced capabilities of IT have enabled the dynamics of "marketing metrics". In particular, the spread of enterprise software applications in business (e.g. ERP and CRM systems) enables the high efficiency of information processing and evaluation necessary for "performance management" as well as the "monitoring that enables the use of alternative metrics" (Seggie et al. 2007, p. 836).

Therefore, within a value-based CRM - as a customer oriented specification of the principle of value-based management (Meyer and Schaffer 2003, p. 64) - an exclusive mutual alignment of marketing and IT is no longer sufficient, but requires the extension of the interface view 
to the perspective of financial management.

In the following, we first describe the key aspects of a mutual alignment of marketing and IT in the context of a value-based CRM in order to further analyze the additional perspective of financial management to complete the triad.

\subsection{Mutual Alignment of Marketing and IT}

Already in the 1980s it was recognized that the use of IT may result in a fundamental redesign of value chains and improve organizational efficiency (Davenport and Short 1990; Porter 1987). Particularly the Internet and the implementation of enterprise software applications introduced a new period of innovation for the enterprise-wide application of IT. In addition, McAfee and Brynjolfsson (2008, p. 103) found out in an extensive study that "IT appears to be much more strongly correlated with the changes in the competitive dynamics than R\&D does." The controversial discussion about the actual contribution of IT to business performance (Anderson et al. 2006; Lim et al. 2004) is also reflected in the results of numerous studies on the implementation of CRM systems. Whereas on the one hand the failures of CRM projects have mainly been attributed to technological aspects (e.g. Fjemestad and Romano 2003), on the other hand a number of studies show that IT plays a substantial role in CRM implementation and that a positive link between the company's investment in CRM systems and the performance of the CRM exists (e.g. Jayachandran et al. 2005; Reinartz et al. 2004). These results demonstrate that "IT/Business Alignment"7, which has been investigated for a long time, also plays a central role for CRM. Applied to the CRM context, it follows that a close integration of the business model and customer-oriented business processes - and thus of marketing strategy and marketing processes - with the alignment of IT becomes necessary (Kale 2004, p. 46; Rigby et al. 2002).

However, the strategic and operational coordination within the CRM between the functional requirements of marketing and the technical capabilities of IT as well as the cooperation of these areas is often difficult due to different goals, different ways of thinking, and a different language. Therefore, in business practice companies first aligned their IT with the strategy and the processes as well as with the resulting goals and requirements of the CRM (Ting-Peng and Tanniru 2007, p. 10). CRM systems are particularly used for the provision of customized and aggregated data across all customers, for the multichannel management which implements the results of the company's strategy and the value creation process into value-adding activities with customers, as well as for providing adequate support to customer-centric processes in all phases of the customer life cycle (Zablah et al. 2004, p. 479). Thus, a basis for increasing the efficiency of marketing is provided.

However, focusing just on the ability of IT to support strategy and processes bears the risk of not utilizing the full potential of innovative technologies (IT as an "enabler") and thereby losing market shares to competitors (McAfee and Brynjolfsson 2008, p. 103). Thus, modern IT not only provides new interaction and communication channels (via the Internet and mobile communications), a personalized and context-related interaction with the customer, the creation of customized products and services, and new business models based on these (Goldenberg 2005, p. 20; Richard et al. 2007, p. 422). On top of that, a company-wide consistent modeling and support of business processes through IT also acts as a catalyst for innovative ideas as well as "an engine for delivering them" (McAfee and Brynjolfsson 2008, p. 103).

Therefore, it is crucial to analyze innovative IT developments in terms of their application to customer-oriented business strategies, goals, and processes and to adjust or re-define the latter and the underlying organizational structures. This alternating interdependence makes clear that IT and marketing resources can only contribute to a company's success if a cross-functional integration and collaboration as well as an alignment with the business goals are achieved.

\subsection{Extension by the Perspective of Financial Management}

Apart from the central importance of the mutual interaction between marketing and IT for the CRM, financial management and its financial methods gain in importance within a value-based management (Rust et al. 2004a, p. 76). As part of the paradigm shift in corporate management it is necessary "to establish an effective method for measuring the success of CRM efforts in a way that supports management decision making" (Richards and Jones 2008, p. 120). This demand is intensified as "intangible assets", such as the customer base, have become an increasingly important part of corporate value (Bauer et al. 2006, p. 231). In the 1980s and 1990s, some authors have therefore already claimed a better integration of marketing and financial management (Hyman and Mathur 2005). However, business practice shows that investments in customer relationships are still mostly based on intuition and experience of the management and are not planned in detail and assessed by financial performance measures as is done with other assets (Reinecke and Fuchs 2006, p. 797). The challenges of identifying and measuring the resulting business value contribution of CRM activities can particularly be attributed to the fact that customer relationships are "intangible assets" and investments in these are transformed into future cash flows only with delay and via complex causeeffect chains (Jain et al. 2007, p. 42; Rust et al. 2004a, p. 76). Since we usually find a lack of financial measures indicating how marketing activities contribute to corporate value, marketing budgets can easily fall victim to cuts, especially in times of crisis when short-term financial results need to be improved (Goldsmith 2004; Marshall 2007).

To support both a customer- and a value-based approach and in addition to traditional performance measures (e.g. sales volume, market share), further measures have been developed firstly, inter alia, to evaluate the effect of marketing activities on intermediate outcomes (e.g. customer satisfaction, customer loyalty), which in turn influence financial performance of the firm (for an overview cf. Gupta and Zeithaml 2006). These measures at least close the "logical gap" between marketing activities and their financial priorities (Kim and Kim 2009, p. 479; O'Sullivan and Abela 2007, p. 80). Thus, for example Buhl et al. (2007) show how the impact of customer satisfaction on loyalty and ultimately on the company's performance can be estimated. Complex cause-effect chains, however, lead to the fact that "often, the promised financial pay offs from improvements in

${ }^{7}$ For a detailed explanation see e.g. Teubner (2006). 
intermediate measures failed to appear" (Seggie et al. 2007, p. 836). At least Wiesel et al. (2008, p. 3) argue that "internally, nonfinancial measures provide managers with good indications of the reasons for change $[\ldots]$, which again benefits the firm's performance." However, to what extent these nonfinancial measures can actually be used to assess the economic value contribution or the "return on investment (ROI)" and distribute company resources to their maximum benefit, remains questionable (Rao and Bharadwaj 2008, p. 17; Richards and Jones 2008, p. 128).

This gain in knowledge has led to an increased discussion of the so-called "marketing metrics" (e.g. Gupta and Zeithaml 2006; Rust et al. 2004a, 2004b). Within these "marketing metrics", customer valuation edges to the center of research as it links the two central issues: "customer relationships" and "financial accountability" (Kumar and George 2007; Richards and Jones 2008, p. 122). Recently, the concept of customer lifetime value (CLV), quantifying the value of a customer using the net present value method, which also forms the basis of $\mathrm{SHV}$, has gained increasing importance among both academics and practitioners (Gupta et al. 2006, p. 139 f; Sackmann et al. 2008, p. 28). It is defined by Dwyer $(1997$, p. 7 ) as "the present value of the expected benefits (e.g., gross margin) less the burdens (e.g., direct costs of servicing and communicating) from customers". Unlike many other methods (such as the $\mathrm{ABC}$ analysis or scoring models), CLV enables a much more comprehensive approach by taking into account all cash flows across the entire lifecycle of a customer relationship. Therefore numerous CLV approaches can be found in literature considering different parameters for the calculation (Gupta et al. 2006). Apart from the key benefits of a future-oriented, long-term, and cashflow-oriented perspective, the practicality of the CLV suffers, however, from the uncertainty resulting from various factors ${ }^{8}$ that accompanies the estimation of future cash flows. Although the consideration of risk is crucial for a riskaverse decision maker - and this is particularly true with regard to the importance of risk in the current financial and economic crisis - an explicit distinction between a deterministic and stochastic world within the CLV approaches is rare
(Buhl and Heinrich 2008, p. 2). Instead of measuring risk by the variance of the CLV, often only a lump-sum reduction of the expected cash flows, a risk-adjusted discount rate, or even the substitution of the discount rate through the theoretically established weighted average cost of capital (WACC) is used (Buhl and Heinrich 2008, p. 4; Kundisch et al. 2008, p. 2).

At least Blattberg and Deighton (1996) managed to break up the isolated and limited perspective on the individual customers by the CLV and allowed strategic decision making on corporate level by pooling all customers in a portfolio, which they called customer equity (CE). This CE is defined by Rust et al. (2004b, p. 110) as "the total of the discounted lifetime values summed over all of the firm's current and potential customers". Hence, the CE reflects the value of all future cash flows expected from all customer relationships. However, through a simple aggregation of the CLVs of all customers the $\mathrm{CE}$ ignores the fact that the risk associated with one customer may be balanced by other, less risky customers, i.e. diversification effects are not taken into account. As a result of these findings regarding the consideration of risk-/returnaspects, a number of financial concepts (e.g. capital asset pricing model, portfolio theory, and real option approaches) have recently been transferred to customer portfolios (e.g. Buhl and Heinrich 2008; Haenlein et al. 2006; Hopkinson and Yu Lum 2002; Kundisch et al. 2008). Such "marketing metrics", based on these approaches and thus taking a future-oriented, long-term, cashfloworiented, and risk-adjusted perspective, allow for an identification and measurement of the economic value contribution and the ROI of marketing. Moreover, acquisition and selection strategies can be based on these measures, thus making a contribution to a value-based decision making within the context of CRM.

Against the background of the information and analysis methods required for these "marketing metrics", however, the positive effect on firm performance of value-based CRM depends on the ability to appropriately integrate modern IT and align it to the corresponding processes (Seggie et al. 2007, p. 836). Only "the improvement in information technology and the availability of customer-level transaction data permits companies to perform detailed analyses instead of relying on aggregate survey-based measures" (Gupta and Lehmann 2006, p. 88). Regarding the so-called (value-based) customer information management, a particular challenge is to integrate CRM systems into the enterprise-wide ICS architecture so that information necessary for the "marketing metrics" is made available in a timely, accurate, and reliable way (Seggie et al. 2007, p. 836). An appropriate marketing performance measurement system, which for example uses a cockpit to display the most important "marketing metrics", allows for a structuring and standardization of the company-wide, value-based planning and control process within marketing (Clark et al. 2006, p. 20) as well as for the strengthening of competitiveness as a result of company-wide and standardized processes (McAfee and Brynjolfsson 2008, p. 103). Moreover, along with CRM systems even the capability of marketing to establish and maintain profitable and long-term customer relationships can be influenced positively (Richards and Jones 2008, p. 126).

Therefore, a selective and alternating collaboration within the triad of marketing, financial management, and IT is crucial for a value-based CRM and for the related objectives of a value-based planning and control of all CRM activities using standardized performance measures.

Based on the findings of this section, a definition of the value-based CRM can be proposed in more detail as follows: A value-based CRM aims to build and manage a portfolio of customer relationships that maximizes corporate value. This requires a comprehensive and valuebased alignment of all corporate activities with the customers, coordinated and appropriate marketing, sales and service concepts as well as a selective use of modern information technology.

\section{Summary and Outlook}

It is widely agreed that customer relationships represent the most valuable assets to firm. Within the value-based management it is therefore crucial that customer relationships should be treated as a portfolio of assets or investments that need to be actively managed to maximize corporate value. Thus, companies not only need to produce, market, and sell high quality products and services, but they

${ }^{8}$ For a detailed overview see e.g. Srivastava et al. (1997). 
also need to establish and maintain longterm and profitable customer relationships. A brief review of literature shows that CRM has developed into a major research focus besides management- and marketing-oriented issues, in particular within BISE. Although different perspectives regarding CRM exist, it is widely agreed that for the complex field of CRM only a holistic alignment of all corporate activities with the customer lead to the desired objectives. However, a limited focus on the mutual alignment of marketing and IT ("align" and "enable") is insufficient within a value-based management, that in particular requires an identification and management of the value contribution of CRM activities and decisions to the corporate value. Therefore, an integration of the additional perspective of financial management as well as the development of appropriate performance measures ("marketing metrics") are inevitable. In doing so, modern IT can consolidate and provide information, required for the determination of and the management control based upon these "marketing metrics" (et al. regarding customer selection and allocation of marketing budgets (e.g. Bruhn et al. 2008; Heiligenthal and Skiera 2007)) and support the implementation of a companywide and consistent performance measurement system.

Looking ahead CRM will remain an important field of research particularly due to technological innovations and the challenges of a value-based management for the internal and external value chain. Thus, it is already evident that e.g. with the recent developments in the context of Web 2.0 (e.g. Bächle 2008; Koch et al. 2007) a new dimension of "networking" is evolving, giving rise to an increased interaction with and integration of customers. Strategies known in the context of "social CRM" or "CRM 2.0" focus on this issue and particularly extend the "classical interactions features" using blogs, forums, and online social networks. Additionally, the analyzed mutual alignment of the triad of marketing, financial management, and IT gains in importance through the increasing virtualization of value-added networks (e.g. Buhl and Winter 2009; Fiedler and Gallenkamp 2008), the impact of sourcing decisions in the context of CRM (e.g. Meyer and Schumacher 2003), and issues concerning the key success factor of the measurement and management of data quality (e.g. Heinrich et al. 2009; Hinrichs 2002). It thus reveals multiple possibilities for further research. Besides the discussed importance of the triad other important issues within CRM implementation projects such as socio-cultural issues regarding the "human factor" (e.g. staff qualifications, incentive systems), legal requirements (for data privacy) have to be taken in account (e.g. Knackstedt et al. 2006; Treiblmaier 2007). Overall, the theoretical conceptualization and review of CRM contains a labyrinth of different perspectives and issues of various disciplines, to which in particular BISE can provide a valuable contribution due to its interdisciplinary and applicationoriented approaches.

\section{References}

Albach H (2001) Shareholder Value und Unternehmenswert - Theoretische Anmerkungen $z u$ einem aktuellen Thema. Zeitschrift für Betriebswirtschaft 71(6):643674

Ambler T (2008) Marketing metrics. In: MJ Baker, SJ Hart (eds) The marketing book, 6th edn. Butterworth-Heinemann, Oxford, pp 414-427

Anderson MC, Banker RD, Ravindran S (2006) Value implications of investments in information technology. Management Science 52(9):1359-1376

Bächle M (2008) Ökonomische Perspektiven des Web 2.0 - Open Innovation Social Commerce und Enterprise 2.0. WIRTSCHAFTSINFORMATIK 50(2):129-132

Bauer $\mathrm{HH}$, Stokburger $\mathrm{G}$, Hammerschmidt $M$ (2006) Marketing Performance: Messen Analysieren - Optimieren. Gabler, Wiesbaden

Becker JU, Greve G, Albers S (2009) The impact of technological and organizational implementation of CRM on customer acquisition, maintenance, and retention. International Journal of Research in Marketing 26(3):207-215

Berry LL (1983) Relationship marketing. In: Berry LL, Shostack GL, Upah G (eds) Emerging perspectives on services marketing American Marketing Association, Chicago, pp 25-28

Birker B (2008) CRM-Soll-Prozess einer Dialogmarketingaktion in einem Handelsunternehmen. In: Helmke S, Uebel MF, Dangelmaier W (eds) Effektives Customer Relationship Management, 4th edn. Gabler Wiesbaden, pp 187-204

Blattberg RC, Deighton J (1996) Manage marketing by the customer equity test. Harvard Business Review 74(4):136-144

Brealey RA, Myers SC, Marucs AJ (2007) Fundamentals of corporate finance. McGrawHill, New York

Brocke J, vom, Sonnenberg C, Simons A (2009) Wertorientierte Gestaltung von Informationssystemen: Konzeption und Anwendung einer Potenzialmodellierung am Beispiel Serviceorientierter Architekturen. WIRTSCHAFTSINFORMATIK 51(3):261-272

Bruhn M, Georgi D, Tuzovic S (2008) Customer equity management as formative secondorder construct. Journal of Business Research 61(12):1292-1301
Buhl HU, Heinrich B (2008) Valuing customer portfolios under risk-return-aspects: A model-based approach and its application in the financial services industry. Academy of Marketing Science Review 12(5):1-32

Buhl HU, Winter R (2009) Vollvirtualisierung - Beitrag der Wirtschaftsinformatik zu einer Vision. WIRTSCHAFTSINFORMATIK 51(2):157-160

Buhl HU, Kundisch D, Schackmann N, Renz A (2007) Spezifizierung des Kano-Modells zur Messung von Kundenzufriedenheit. In: Oberweis A, Weinhardt C, Gimpel H, Koschmider A, Pankratius V, Schnizler B (eds) Wirtschaftsinformatik 2007 eOrganisation: Service-, Prozess-, MarketEngineering, Karlsruhe, pp 879-896

Bush RP, Underwood JH, Sherrell DL (2006) Examining the relationship marketing, marketing productivity paradigm: Establishing an agenda for current and future research. Journal of Relationship Marketing 6(2):933

Buttle F (2004) Customer relationship management: concepts and tools. Elsevier/ Butterworth-Heinemann, Oxford

Christopher M, Payne A, Ballantyne D (1991) Relationship marketing. ButterworthHeinemann, Oxford

Clark BH, Abela AV, Ambler T (2006) Behind the wheel. Marketing Management 15(3):19-23

Copeland T, Koller T, Murrin J (1993) Unternehmenswert. Methoden und Strategien für eine wertorientierte Unternehmensführung. Campus, Frankfurt

Da Silva RV, Rahimi ID (2007) A critical success factor model for CRM implementation. International Journal of Electronic Customer Relationship Management 1(1):3-15

Danielson MG, Heck JL, Shaffer DR (2008) Shareholder theory - how opponents and proponents both get it wrong. Journal of Applied Finance 18(2):62-66

Davenport TH, Short JE (1990) The new industrial engineering: information technology and business process redesign. Sloan Management Review 31(4):11-27

Doherty NF, Lockett NJ (2007) Closing the gap between the expectations of relationship marketing and the reality of E-CRM. International Journal of E-Business Research 3(2):I-VI

Dwyer FR (1997) Customer lifetime valuation to support marketing decision making. Journal of Direct Marketing 11(4):6-13

Elmuti D, Jia H, Gray D (2009) Customer relationship management strategic application and organizational effectiveness: an empirical investigation. Journal of Strategic Marketing 17(1):75-96

Fiedler M, Gallenkamp J (2008) Virtualisierung der Kommunikation - Der Beitrag von Informationsreichhaltigkeit für Kooperationen. WIRTSCHAFTSINFORMATIK 50(6):472481

Fjemestad J, Romano NC (2003) Electronic customer relationship management: revisiting the general principles of usability and resistance - an integrative implementation framework. Business Process Management Journal 9(5):572-591

Ford D (1990) Understanding business markets: interaction, relationships, network. Academic, London

Goldenberg B (2005) Real-time CRM: a business revolution in the making. CRM Magazine 9(7):20 


\section{Abstract}

Martin S. Gneiser

\section{Value-Based CRM}

The Interaction of the Triad of Marketing, Financial Management, and IT

One major development within business practice is the increasing interest in customer relationship management (CRM) in recent years. CRM thereby focuses on establishing and maintaining profitable relationships with the customer using modern information technology (IT) and has emerged as a major research field in business and information systems engineering. However, despite huge investments many CRM projects fail to achieve their objectives as the complex and interdisciplinary nature of CRM is not addressed adequately. In fact an adoption of a customer-centric orientation within a value-based management requires not only a cross-functional integration of different business departments but also a selectively adjusted collaboration of those departments.

The paper provides an overview of the state of the art of CRM in literature as well as current practices in companies. Furthermore it outlines the specific challenges of a value-based CRM for the cross-functional integration and collaboration of marketing, financial management, and IT. Thus, in addition to a mutual alignment of marketing and IT, a value-based analysis, planning, and controlling of CRM-activities requires the development and implementation of standardized performance measurements and their adequate ITsupport.

Keywords: CRM, CRM-systems, Valuebased management
Goldsmith RE (2004) Current and future trends in marketing and their implications for the discipline. Journal of Marketing Theory and Practice 12(4):10-17

Gu F (2005) Innovation future earnings, and market efficiency. Journal of Accounting Auditing \& Finance 20(4):385-418

Gupta S, Lehmann DR (2006) Customer lifetime value and firm valuation. Journal of Relationship Marketing 5(2/3):87-110

Gupta S, Zeithaml VA (2006) Customer metrics and their impact on financial performance. Marketing Science 25(6):718-739

Gupta S, Hanssen DM, Hardie BGS, Kahn W, Kumar V, Lin N, Ravishanker N, Sriram S (2006) Modeling customer lifetime value. Journal of Service Research 9(2):139-155

Haenlein M, Kaplan AM, Schoder D (2006) Valuing the real option of abandoning unprofitable customers when calculating customer lifetime value. Journal of Marketing 70(3):5-20

Harker MJ, Egan J (2006) The past and future of relationship marketing. Journal of Marketing Management 22(1):215-242

Hasan M (2003) Ensure success of CRM with a change in mindset. Marketing News 37(8):16

Heiligenthal J, Skiera B (2007) Optimale Verteilung eines Budgets auf Aktivitäten zur Kundenakquisition, Kundenbindung und Add-on-Selling. Zeitschrift fü Betriebswirtschaft 77(Special Issue 3):117141

Heinrich B, Kaiser M, Klier M (2009) A procedure to develop metrics for currency and its application in CRM. ACM Journal of Data and Information Quality 1(1): Article 5

Hinrichs H (2002) Datenqualitätsmanagement in Data Warehouse-Systemen. Dissertation Universität Oldenburg, Oldenburg

Hippner H (2005) Die (R) Evolution des Customer Relationship Management. Marketing ZFP 27(2):115-134

Hippner H, Rentzmann R, Wilde KD (2007) Aufbau und Funktionalitäten von CRM Systemen. In: Hippner H, Wilde KD (eds) Grundlagen des CRM, 2nd edn. Gabler, Wiesbaden, pp 45-74

Hopkinson G, Yu Lum C (2002) Valuing customer relationships: using the capital asse pricing model (CAPM) to incorporate relationship risk. Journal of Targeting Measurement \& Analysis for Marketing 10(3):220 232

Hyman Mr, Mathur I (2005) Retrospective and prospective views on the marketing/finance interface. Journal of the Academy of Marketing Science 33(4):390400

Iriana R, Buttle F (2006) Strategic, operational, and analytical customer relationship management: attributes and measures. Journal of Relationship Marketing 5(4):23-42

Ittner CD, Larcker DF (1998) Are nonfinancial measures leading indicators of financial performance? An analysis of customer satisfaction. Journal of Accounting Research 36(Supplement):1-35

Jackson TW (2005) CRM: from 'art to science'. Journal of Database Marketing \& Customer Strategy Management 13(1):76-92

Jain R, Jain S, Dhar U (2007) Curel: a scale for measuring customer relationship management effectiveness in service sector. Journal of Services Research 7(1):37-58

Jayachandran S, Sharma S, Kaufman P, Raman $P$ (2005) The role of relational information process and technology use in customer relationship management. Journal of Marketing 69(4):177-192
Kale SH (2004) CRM failure and the seven deadly sins. Marketing Management 13(5):42-46

Keown AJ, Maritn D, Petty JW (2008) Foundations of finance. Pearson Prentice-Hall, Upper Saddle River

Kim H, Kim Y (2009) A CRM performance measurement framework: its development process and application. Industrial Marketing Management 38(4):477-489

Knackstedt R, Brelage C, Kaufmann NC (2006) Entwicklung rechtssicherer Web-Anwendungen. WIRTSCHAFTSINFORMATIK 48(1): 27-35

Koch M, Richter A, Schlosser A (2007) Produkte zum IT-gestützten Social Networking in Unternehmen. WIRTSCHAFTSINFORMATIK 49(6):448-455

Kotler P, Armstrong G (2004) Principles of marketing, 10th edn. Prentice-Hall, Upper Saddle River

Krcmar H (2005) Informationsmanagement, 4th edn. Springer, Berlin

Kumar V, George M (2007) Measuring and maximizing customer equity: a critical analysis. Journal of the Academy of Marketing Science 35(2):157-171

Kumar V, Ramani G, Bohling T (2004) Customer lifetime value approaches and best practice applications. Journal of Interactive Marketing 18(3):60-72

Kundisch D, Sackmann S, Ruch M (2008) CRM and customer portfolio management for e-tailers. In: Proceedings 41th annual Hawaii international conference on system sciences (HICSS-41), Hawaii

Lim J, Richardson VJ, Roberts TL (2004) Information technology investment and firm performance: a meta-analysis. In: Proceedings 37th annual Hawaii international conference on system science (HICSS-37), Hawaii

Marketingcharts (2008) CRM Application revenue set to double in value. http:// www.marketingcharts.com/direct/crmapplications-revenue-set-to-double-invalue-2225. Accessed 2009-01-15

Marketing Science Institute (2006) 20062008 MSI research priorities. Cambridge, USA

Marshall J (2007) Are finance and marketing getting closer? Financial Executive 23(2):46-48

McAfee A, Brynjolfsson E (2008) Investing in the IT. That makes a competitive difference. Harvard Business Review 86(7):98-107

Meyer M, Kolbe LM (2005) Integration of customer relationship management: status quo and implications for research and practice. Journal of Strategic Marketing 13(3):175-198

Meyer A, Schaffer M (2003) Die Kundenbeziehung als ein zentraler Unternehmenswert - Kundenorientierung als Werttreiber der Kundenbeziehung. In: Günter B, Helm S (eds) Kundenwert: Grundlagen - Innovative Konzepte - Praktische Umsetzung, 2nd edn. Gabler, Wiesbaden, pp 61-86

Meyer M, Schumacher J (2003) Outsourcing von CRM-Teilprozessen an Betreiber von Internetmarktplätzen. WIRTSCHAFTSINFORMATIK 45(2):165-175

Ngai EWT (2005) Customer relationship management research (1992-2002): an academic literature review and classification. Marketing Intelligence \& Planning 23(6/7):582-605

O'Sullivan D, Abela A (2007) Marketing performance measurement ability and firm performance. Journal of Marketing 71(2):7993 
Payne A, Frow P (2005) A strategic framework for customer relationship management. Journal of Marketing 69(4):167-176

Payne A, Frow P (2006) Customer relationship management: from strategy to implementation. Journal of Marketing Management 22(1):135-168

Peppers D, Rogers M (2001) The one to one B2B - Customer development strategies for the business-to-business world. Currency/Doubleda, New York

Peppers D, Rogers M, Dorf B (1999) Is your company ready for one-to-one marketing? Harvard Business Review 77(1):151-161

Porter ME (1987) From competitive advantage to corporate strategy. Harvard Business Review 65(3):43-59

Raman P, Wittmann CM, Rauseo NA (2006) Leveraging CRM for sales: the role of organizational capabilities in successful CRM implementation. Journal of Personal Selling \& Sales Management 26(1):39-53

Rao R, Bharadwaj N (2008) Marketing initiatives, expected cash flows, and shareholders' wealth. Journal of Marketing 72(1):1626

Rappaport A (1986) Creating shareholder value. The Free Press, New York

Reinartz WJ, Krafft M, Hoyer WD (2004) The Customer relationship management process: its measurement and impact on performance. Journal of Marketing Research 41(3):293-305

Reinecke S, Fuchs D (2006) Marketingbudgetierung. Grundlagen, Herausforderungen und Lösungsansätze. In: Reinecke $S$, Tomczak T (eds) Handbuch Marketingcontrolling, 2nd edn. Gabler, Wiesbaden, pp 795-818

Richard JE, Thirkell PC, Huff SL (2007) The strategic value of CRM: a technology adoption perspective. Journal of Strategic Marketing 15(5):421-439
Richards KA, Jones E (2008) Customer relationship management: finding value drivers. Industrial Marketing Management 37(2):120-130

Riemer K, Totz C, Klein S (2002) Vergleichende Buchbesprechung: CustomerRelationship-Management. WIRTSCHAFTSINFORMATIK 44(6):600-607

Rigby DK, Reichheld FF, Schefter P (2002) Avoid the four perils of CRM. Harvard Business Review 80(2):101-109

Rust RT, Ambler T, Carpenter GS, Kumar V Srivastava RK (2004a) Measuring marketing productivity: current knowledge and future directions. Journal of Marketing 68(4):76-89

Rust RT, Lemon KN, ZeithamI VA (2004b) Return on marketing: using customer equity to focus marketing strategy. Journal of Marketing 68(1):109-127

Sackmann S, Kundisch D, Ruch M (2008) CRM Kundenbewertung und integrierte RiskReturn-Steuerung - Zum Status quo des betrieblichen Einsatzes. HMD Praxis der Wirtschaftsinformatik 44(259):21-32

Schierholz R, Kolbe LM, Romano NC, Fjermestad (2006) Minitrack introduction: electronic and mobile customer relationship management. In: Proceedings 39th annual Hawaii international conference on system science (HICCS-39), Hawaii

Seggie SH, Cavusgil E, Phelan SE (2007) Measurement of return on marketing investment: a conceptual framework and the future of marketing metrics. Industrial Marketing Management 36(6):834-841

Seidel B CRM-Markt auf Wachstumskurs. http://www.zdnet.de/it business strategische_planung_crm_markt_auf_ wachstumskurs story-1100001539186635-1.htm. Accessed 2009-03-21

Srivastava R, Tasadduq S, Fahey L (1997) Driving shareholder value: the role of marketing in reducing vulnerability and volatility of cash flows. Journal of Market Focused Management 2(1):49-64

Stahlknecht P, Hasenkamp U (2005) Einführung in die Wirtschaftsinformatik, 11th edn. Springer, Berlin

Stefanou C, Sarmaniotis C, Stafyla A (2003) CRM and customer-centric knowledge management: an empirical research. Business Process Management Journal 9(5):617-634

Teo TSH, Devadoss P, Pan SL (2006) Towards a holistic perspective of customer relationship management (CRM) implementation: a case study of the Housing and Development Board, Singapore. Decision Support Systems 42(3):1613-1627

Teubner A (2006) IT/business alignment. WIRTSCHAFTSINFORMATIK 48(5):368-371

Ting-Peng L, Tanniru M (2007) Special section: customer-centric information systems. Journal of Management Information Systems 23(3):9-15

Treiblmaier H (2007) Beziehungsmarketing aus Kundensicht. WIRTSCHAFTSINFORMATIK 49(1):42-48

Wehmeyer K (2005) Aligning IT and marketing - the impact of database marketing and CRM. Journal of Database Marketing \& Customer Strategy Management 12(3):243-256

Wiesel T, Skiera B, Villanueva J (2008) Customer equity: an integral part of financial reporting. Journal of Marketing 72(2):1-14

Xu M, Walton J (2005) Gaining customer knowledge through analytical CRM. Industrial Management \& Data Systems 105(7):955-971

Zablah AR, Bellenger DN, Johnston WJ (2004) An evaluation of divergent perspectives on customer relationship management: towards a common understanding of an emerging phenomenon. Industrial Marketing Management 33(6):475-489 